\title{
STUDYING SOME OF THE EARTH TUBE HEAT EXCHANGER AND SOILS PROPERTIES
}

\section{H. Hatem ${ }^{1}$. R. El-Kilani ${ }^{2}$. Matthias Schick ${ }^{3}$ and H. R. Elshemy ${ }^{4}$}

\section{ABSTRACT}

In this paper the composition and thermal property of soil and pipe of earth tube heat exchanger are discussed. The main factors that impact the soil thermal properties and several commonly-used pipe materials are studied. The impact of soil thermal conductivity and pipe thermal conductivity on the soil temperature field around the buried pipe is very important. As an energy-saving and environment friendly air conditioning technology, earth tube heat exchanger has been utilized wildly for some years. It is necessary to study in detail soil properties and pipe materials for utilizing earth tube heat exchanger successfully. The thermal conductivity for sandy soil is higher than sandy clay loam soil and heat exchange rate between air in metal pipe and soil achieve more 5 time for PVC pipe and wet soil with $15 \%$ moisture achieve heat exchange rate to air in pipe by $5 \%$ more dry soil.

\section{INTRODUCTION}

$\mathrm{S}$ oil temperature is one of the most important factors affecting design and performance of earth-tube heat exchanger systems. Soil temperatures vary with soil type, depth, moisture content, time of year, and geographic location (Sabau, S. et al., 1997).

The design of a ground heat exchanger for a GHP system requires, at a minimum, information about the properties of the heat exchanger: the size of the U-tubes, the material of the pipe, etc. The design also requires some knowledge of the thermal properties of the soil, namely thermal conductivity, undisturbed soil temperature and the interaction between the soil and the pipe (Guozhong Wu. et al., 2003).

1 Prof., Agric. Eng. Dept., Fac. of Agric., Cairo Univ.

2 Asisst. Prof, Agric. Eng. Dept., Fac. of Agric., Cairo Univ.

3 Prof., Institute of Agric. Eng, Switzerland.

4 Assist. Lecturer, Agric. Eng. Dept., Fac. of Agric., Cairo Univ. 
Heat transfer in soils plays an important part in many types of problems in such varied fields as engineering, geophysics, meteorology and agriculture. An under standing of the thermal behavior of soil helps one deal with these problems, and values of the soil's thermal properties are required for quantitative analysis (Hongming Fan, 1999).

Soil thermal properties are of great importance in many engineering projects and other situations where heat transfer takes place in the soil. For example, Agricultural "soil" is a complex, dynamic and living they are of great importance in the design of roads, system where biological processes continuously take airfields, pipelines or buildings in cold regions as well place. The term soil, as used by engineers, refers to a as underground power cables, hot water pipes or cold- complicated material consisting of solid particles of gas pipelines in unfrozen ground.

Soil thermal conductivity is the most important property parameters, and a lot of complicated problem involved in heat transfer between buried pipe and soil in earth tube heat exchanger, such as freezing and thaw of soil, flow of groundwater, simultaneous conduction of heat and wet etc., can be simplified by using an equivalent thermal conductivity of soil, which can be obtained by measuring and analyzing through experiment (Bose J E. et al., 1983).

Soil is a kind of complicated substance with its inhomogeneity and multiphase. In order to be understand easily, it is used to be divided into mineral substance (solid state), organic matter (solid state ), water (liquid state) and air (gas state), seen form Table (1). It is necessary and important to study soil property for utilizing earth tube successfully. And thermal property of soil includes: soil heat conduction coefficient (thermal conductivity), density, specific heat, temperature, thermal resistance and thermal diffusion degree, etc.. 
Tabal. 1 Main parameters of composition in soil (standard atmosphere, $\left.20^{\circ} \mathrm{C}\right)$ (Sabau, S. et al .,1997).

\begin{tabular}{|l|c|c|c|c|}
\hline Composition & $\begin{array}{c}\text { Density } \\
\mathbf{k g} / \mathbf{m 3}\end{array}$ & $\begin{array}{c}\text { Specific } \\
\text { heat of } \\
\text { quality } \\
\mathbf{k J} /(\mathbf{k g} \cdot \mathbf{C})\end{array}$ & $\begin{array}{c}\text { Specific } \\
\text { heat of } \\
\text { volume } \\
\mathbf{k J} /(\mathbf{m 3} \cdot \mathbf{C})\end{array}$ & $\begin{array}{c}\text { Thermal } \\
\text { conductivityW/(m·C) }\end{array}$ \\
\hline $\begin{array}{l}\text { Mineral } \\
\text { substance }\end{array}$ & 2650 & 0.733 & 1942 & $2.93 \sim 8.37$ \\
\hline $\begin{array}{l}\text { Organic } \\
\text { matter }\end{array}$ & 1300 & 1.926 & 2504 & 0.251 \\
\hline Water & 1000 & 4.186 & 4187 & 0.595 \\
\hline Air & 1.2 & 1.005 & 1.2 & 0.026 \\
\hline
\end{tabular}

\section{PROPERTY OF BURIED PIPE}

It is important to select suitable material for buried pipe. In the fifties of the 20th century, the metal pipes are generally adopted, such as the zincplated steel and the copper pipes. Until later stage of the seventies, they are replaced by the silent stock pipes (Hongming Fan et al., 1999). Though the heat conduction performance of the silent stock pipe is worse than that of the metal, its thermal resistance is matched with that of soil well, and the anticorrosive performance is good, silent stock pipes (Guozhong Wu. et al., 2003).

But now with economic problems metal is not a good idea so a lot of researches Work to get a new pipe material

The objective of this study was to determine some of natural and thermal properties for two types of soil: sandy and Clay loam including, True density, bulk density, thermal conductivity., Determining some of natural and thermal properties for four different of pipe materials: $P V C$, iron and galvanized iron including thermal conductivity. And Determining heat transfer rate from soil to air (in pipe). 


\section{MATERIAL AND METHODS}

This research was conducted in Agricultural Engineering Department, Faculty of Agriculture, Cairo University during the year 2013.

\section{Soil Properties}

The lab experimental was carried out using two different soil samples. These samples were sandy clay-loam soil and sandy soils.

\subsection{Physical properties of soil}

\subsubsection{Soil Bulk density}

Bulk density is an indicator of soil compaction. It is calculated as the dry weight of soil divided by its volume. This volume includes the volume of soil particles and the volume of poresamong soil particles. Bulk density is typically expressed in $\mathrm{g} / \mathrm{cm}^{3}$ (Randall J. et al., 2007 )

The bulk density of soil depends greatly on the mineral make up of soil and the degree of compaction. The bulk density is the ratio of the mass of the sample to its container volume.

It was measured by weighing a filled measuring cylinder with known volume and calculated according to (Calvin W, 2004 )

$$
\rho_{b}=\frac{\mathbf{M}}{\mathbf{V}}
$$

Where

$\rho_{b} \quad$ : Bulk density $\left(\mathrm{g} / \mathrm{cm}^{3}\right)$.

M : Mass of sample (g).

$\mathrm{V}$ : Volume of the sample $\left(\mathrm{cm}^{3}\right)$.

\subsubsection{True density:}

The soil true density is defined as the ratio of mass of the sample to its true volume (Calvin W, 2004 ).

$$
\rho_{s}=\frac{\mathbf{M}}{\mathbf{V}_{\mathbf{c}}}
$$


Where

$\rho_{s} \quad: \quad$ Solid density $\left(\mathrm{g} / \mathrm{cm}^{3}\right)$.

$\mathrm{M} \quad$ : Mass of samples $(\mathrm{g})$.

$\mathrm{V}_{\mathrm{c}}$ : Volume of the samples $\left(\mathrm{cm}^{3}\right)$.

\subsubsection{Soil Porosity}

The pore space of a soil is that portion of the soil volume occupied by air and water material and was calculated as (Calvin W, 2004):

$$
\varepsilon=\left[1-\frac{\rho_{b}}{\rho_{s}}\right] .100
$$

Where

$\varepsilon:$ Porosity (\%).

\subsection{Thermal properties of soil}

\subsubsection{Soil thermal conductivity}

Soil thermal properties are strongly influenced by the soil volumetric water content, volume fraction of solids and volume fraction of air. Air is a poor thermal conductor and reduces the effectiveness of the solid and liquid phases to conduct heat. While the solid phase has the highest conductivity it is the variability of soil moisture that largely determines thermal conductivity.

Temperature variations are most extreme at the surface of the soil and these variations are transferred to sub surface layers but at reduced rates as depth increases.

One possible way of assessing soil thermal properties is the analysis of soil temperature variations versus depth Fourier's law (Holman, 1986).

$$
q / A=K \frac{\Delta T}{\Delta Z}
$$

Where:

q/A : heat flux or rate of heat transfer per unit area $\mathrm{J} \cdot \mathrm{m}^{-2} \cdot \mathrm{s}^{-1}$ or $\mathrm{W} \cdot \mathrm{m}^{-2}$.

$\mathrm{K}$ : thermal conductivity $\mathrm{W} \cdot \mathrm{m}^{-1} \cdot \mathrm{K}^{-1}$.

$\frac{\Delta T}{\Delta Z}$ : the gradient of temperature (change in temp/change in depth $\mathrm{K} \cdot \mathrm{m}^{-1}$. 
Soil thermal conductivity was determined using two methods

1. Graphical analysis to describe the thermal distribution around the heater.

2. conduction shape factor.

\section{Graphical analysis:}

Consider the two - dimensional system shown in Figure (1). The inside surface is maintained at some temperature $T_{1}$, and the outer surface is maintained temperature $\mathrm{T}_{2}$. We wish to calculate the heat transfer. Isotherms and heat- flow lines have been sketched to aid in this calculation. Consequently; the thermal conductivity could be estimated according to (Holman , 1986) :

$$
\mathrm{q}=\frac{M}{N} k \Delta \boldsymbol{T}_{\text {over all }}
$$

where

$M:$ the number of heat-flow lanes.

$N$ : the number of temperature increments between the inner and outer surfaces.

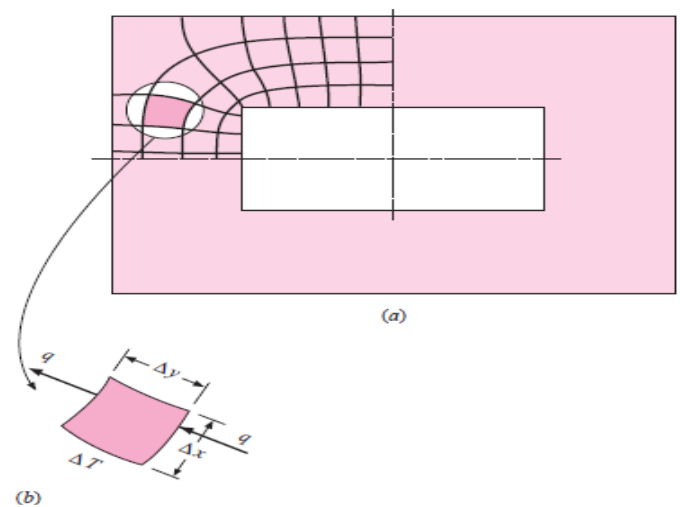

Fig. (1) Sketch showing element used for curvilinear-square analysis of two dimensional heat flow(Holman ,1986).

The Graphical analysis was used to describe the thermal distribution around the heater centre in a wood box 50X 50X20 cm shown in Figure (2a) and thermocouples sensors were distributed in four different 
directions on a distance from heater 5, 10 and $15 \mathrm{~cm}$ as shown in Figure (2b).

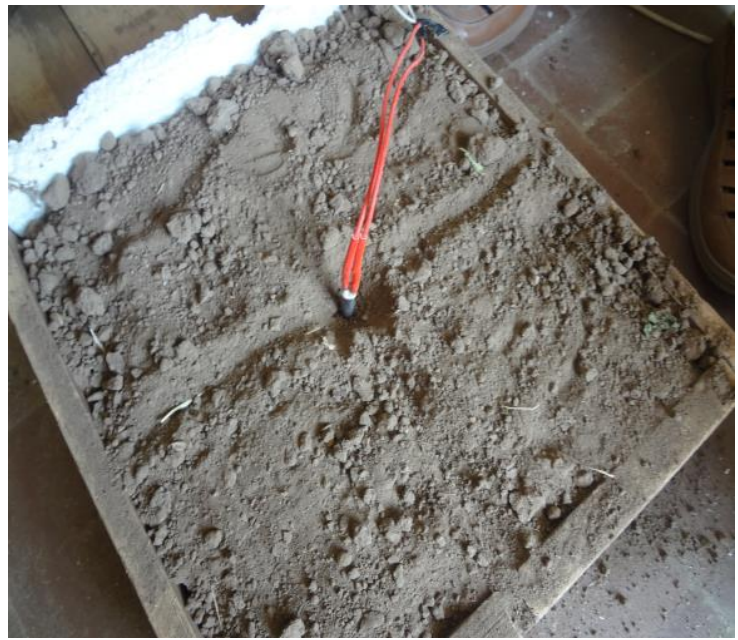

(a)

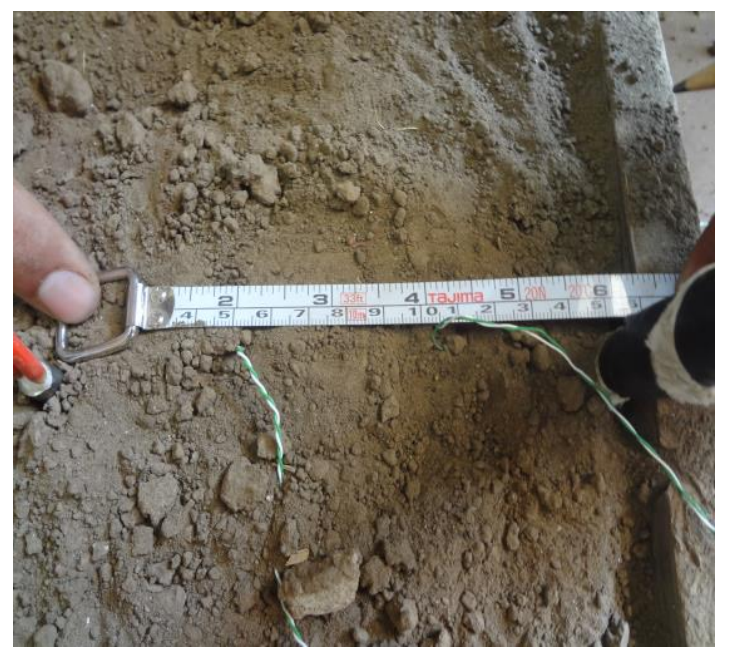

(b)

Fig. (2) a show the heat source in the centre of the box. Fig. (2)b show the distance between sensors.

Conduction shape factor:

In a two - dimensional system where only two temperature limits are involved, we may define a conduction shape factor $S$ such that (Holman.,1986)

$$
q=k s \Delta T_{\text {over all }}
$$

Where

q: heat transfer rate, w .

$\mathrm{S}$ : shape factor, $\mathrm{m}$.

$\Delta \mathrm{T}$ : difference temperature degree, ${ }^{\circ} \mathrm{C}$.

$\mathrm{K}$ : thermal conductivity $\mathrm{W} \cdot \mathrm{m}^{-1} \cdot \mathrm{K}^{-1}$.

\section{The value $S$ calculated by (Holman.,1986)}

$$
\mathrm{S}=\frac{2 \pi L}{\operatorname{Ln}\left(\frac{2 l}{r}\right)}
$$




\section{Where}

$\mathrm{q}$ : heat transfer rate $\mathrm{W}$.

$\mathrm{L}$ : pipe length $\mathrm{m}$.

$\mathrm{K}$ : thermal conductivity $\mathrm{W} / \mathrm{m} .{ }^{\circ} \mathrm{C}$.

$\mathrm{T}_{\mathrm{i}}$ : inner temperature, ${ }^{\circ} \mathrm{C}$.

To : outer temperature, ${ }^{\circ} \mathrm{C}$.

ro: outer radius, $\mathrm{m}$.

ri : inner radius, $\mathrm{m}$.

\subsection{Pipe materials thermal conductivity}

The thermal conductivity was determined for four different materials of pipe through the following experiment as shown in Fig. (3). A heat source $(40 \mathrm{~W})$ was placed in each radial cylinder (pipe), the opened sections of pipe were closed or isolated by polystyrene $(2 \mathrm{~cm}$ thickness). The wall inside and outside temperature was measured using ALMEMO® 2290-8 thermocouples The measured specifications of each pipe were that is (in $\mathrm{mm}$ ): length, $\mathrm{L}$, diameter, $\mathrm{D}$ and thickness, T, was measured using an electronic digital caliper with an accuracy of $0.01 \mathrm{~mm}$

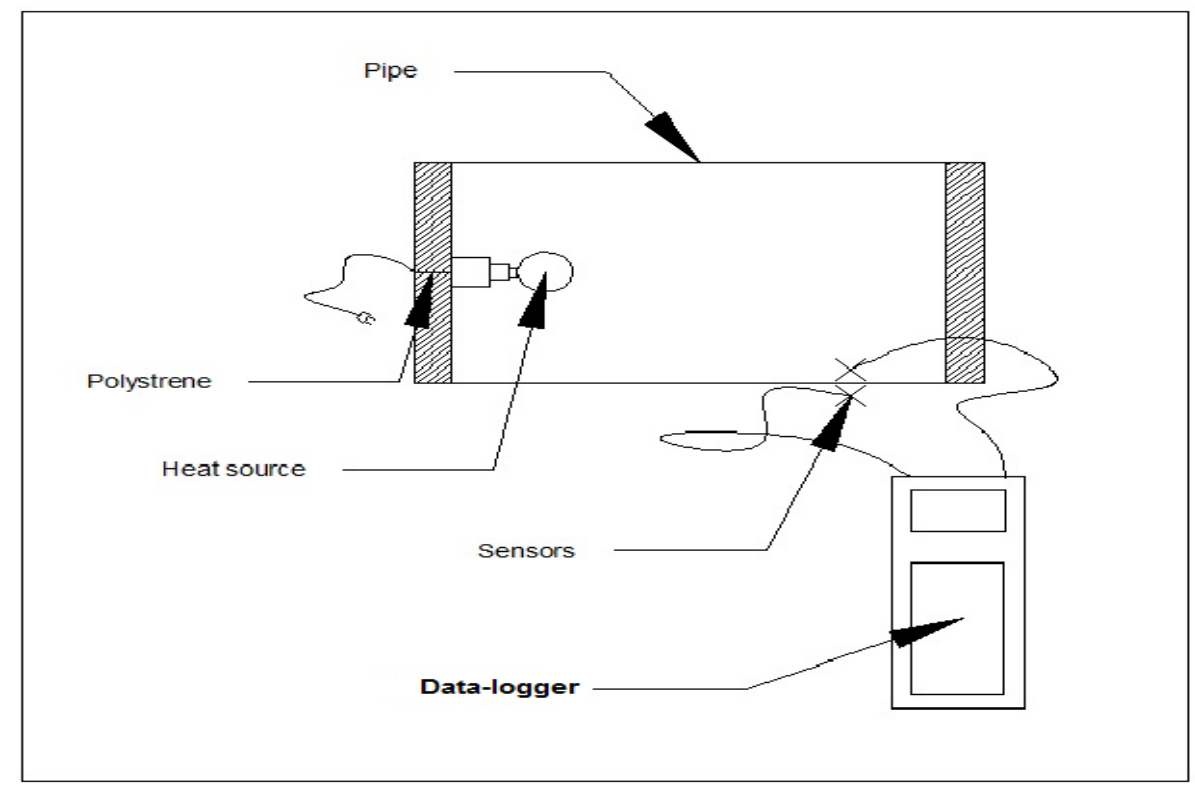

Fig.(3) The components of the experiment 
Thermal conductivity was calculated according to the following equation (Holman , 1986):

$$
q=\frac{2 \pi l k(T i-T o)}{\operatorname{Ln}\left(\frac{r o}{r i}\right)}
$$

Where

$\mathrm{q}$ : heat transfer rate $\mathrm{W}$.

$\mathrm{L}$ : pipe length $\mathrm{m}$.

$\mathrm{K}$ : thermal conductivity $\mathrm{W} / \mathrm{m} .{ }^{\circ} \mathrm{C}$.

$\mathrm{T}_{\mathrm{i}}$ : inner temperature, ${ }^{\circ} \mathrm{C}$.

$\mathrm{T}_{\mathrm{o}}$ : outer temperature, ${ }^{\circ} \mathrm{C}$.

$\mathrm{r}_{\mathrm{o}}$ : outer radius, $\mathrm{m}$.

$r_{i}$ : inner radius, $m$.

Table. 2 Pipes specifications used in the experiment

\begin{tabular}{|c|c|c|c|c|}
\cline { 2 - 5 } \multicolumn{1}{c|}{} & $\begin{array}{c}\text { Outer } \\
\text { diameter(mm) }\end{array}$ & $\begin{array}{c}\text { Inner } \\
\text { diameter(mm) }\end{array}$ & $\begin{array}{c}\text { Thickness } \\
(\mathbf{m m})\end{array}$ & $\begin{array}{c}\text { Length } \\
(\mathbf{c m})\end{array}$ \\
\hline PVC & 50 & 47 & 1.6 & 150 \\
\hline Steel & 50 & 47 & 1.5 & 150 \\
\hline $\begin{array}{c}\text { Galvanized } \\
\text { steel }\end{array}$ & 50 & 47 & 1.5 & 150 \\
\hline
\end{tabular}

\subsection{Heat transfer rate from air to soil:}

The heating rate with time is of primary importance and can be estimated from both the electrical power and the fluid temperature difference across the heater. The electric power may be plotted in Watts.

The heat input rate estimate from the temperate difference of the circulating fluid across the pipe according to (Michael, J.2000).

$$
Q=m^{\bullet} C_{p}(T i-T o)
$$

where

Q : heat input rate, $\mathrm{W}$.

$\mathrm{m}^{\mathrm{o}}$ : air mass flow rate, $\mathrm{kg} / \mathrm{sec}$.

cp : specific heat of circulating fluid, $\mathrm{J} / \mathrm{kg} .{ }^{\circ} \mathrm{C}$.

$\mathrm{Ti}$ : inlet air temperature to pipe, ${ }^{\circ} \mathrm{C}$.

To : outlet air temperature from ground loop, ${ }^{\circ} \mathrm{C}$. 
air- soil heat exchanger experiment was carried out using a wood box $(120 * 60 * 40)$ as shown in Fig. (4). opening slots (50mm diameter) for different box sides in two sides the pipes were troughed three different pipe materials were used. The experimental pipes materials are PVC, steel and galvanized steel. The pipes were installed in the experimental box and subsequently the box was totally filled with the selected soil. from box slots and the box filled totally by a soil (two types of soil were used clay loam and sandy). The soil was cooled using ice. The air was forced by a blower (500 watt, $2200 \mathrm{rpm}$ ) at different velocities. The air velocities were adjusted to be $0.7,1$, and $1.5 \mathrm{~m} / \mathrm{s}$. the air temperatures (out/inlet) for each pipe were measured. And the soil was used with different moisture content $10 \%$ and $15 \%$.

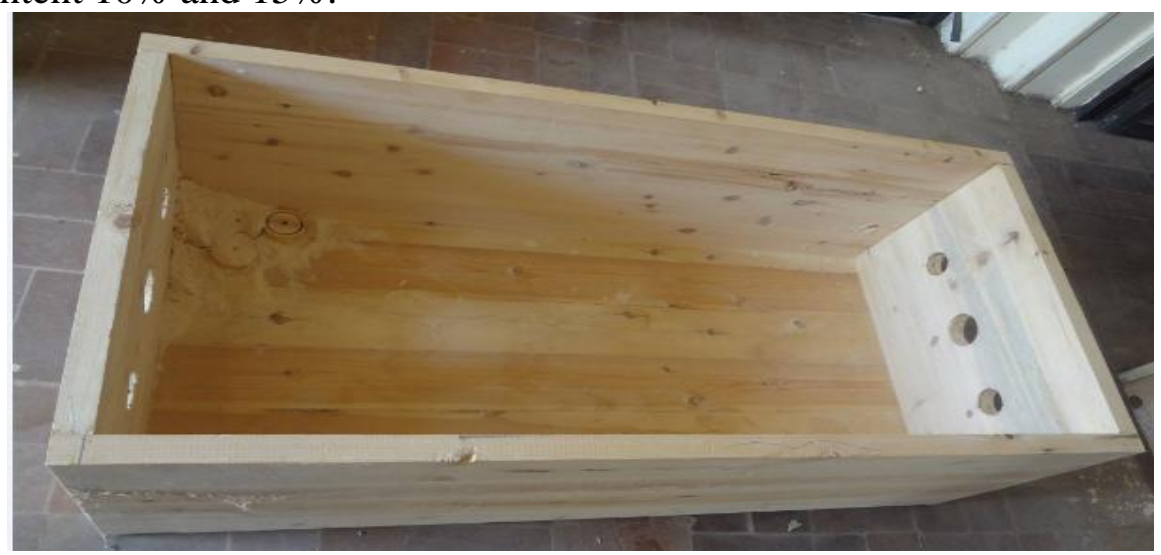

Fig. (4). a wood box with opening slots for different box sides .

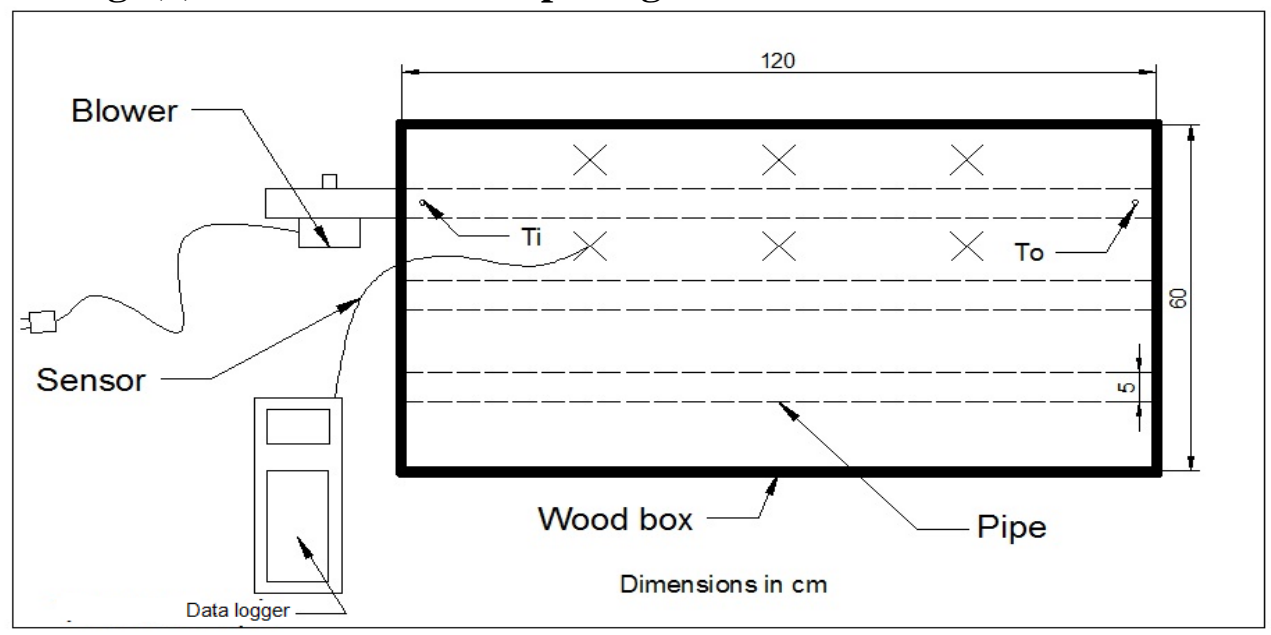

Fig. (5) Plan view for the experiment 


\section{RESULTS AND DISCUSSION}

The present experiment was carried out to estimate some of different properties for soil, pipe materials and the interaction between them. From the obtained results, an earth tube heat exchanger will be designed to enhance the utilization of the geothermal energy in the agricultural sector at the future study.

\section{Physical properties of soil:}

Bulk density, true density and porosity:

Table 3. Illustrate the Bulk density, true density and porosity for sandy soil and sandy clay loam soil

\begin{tabular}{|c|c|c|c|}
\hline Soil type & $\begin{array}{c}\text { Bulk density } \\
\text { g/cm3 }\end{array}$ & $\begin{array}{c}\text { True density } \\
\text { g/cm3 }\end{array}$ & Porosity \\
\hline Sandy clay loam & 1.41 & 2 & $41 \%$ \\
\hline Sandy soil & 1.52 & 2.1 & $30 \%$ \\
\hline
\end{tabular}

Thermal conductivity for pipe material:

The obtained results through showed that the thermal conductivity for steel is the best and PVC is the lowest number as shown as Table (4).

Table 4 . types of the pipe materials and thermal conductivities

\begin{tabular}{|c|c|}
\hline Pipe material & Thermal conductivity \\
\hline PVC & 0.19 \\
\hline Steel & 16.2 \\
\hline Galvanized steel & 8.4 \\
\hline
\end{tabular}

\section{Soil thermal conductivity}

The thermal conductivity of soil under a given set of conditions is most important to the efficiency of earth tube heat exchanger and the results show that the heat transfer in sandy soil is faster than the sandy clay loam soil and heat is transferring in isothermal lines around the heater and the heat distribution increase with content of moisture in two types of soil because the of surface area connection increase according to fourier equation for conduction heat transfer as shown as Fig.(7) and Thermal conductivity( using Graphical analysis and conduction shape factor) was $1.67 \mathrm{~W} / \mathrm{m} \mathrm{K}$ for sandy soil, $0.94 \mathrm{~W} / \mathrm{m} \mathrm{K}$ for sandy clay loam, at densities from 1.23 to $1.59 \mathrm{~g} \mathrm{~cm}-3$ and water contents from 1.4 to $21.2 \%$. The results also show that an increase in the amount of added salts at given moisture content (volumetric solution contents $\theta$ ranged from $0.03-$ $0.12 \mathrm{~m} 3 \mathrm{~m}-3$ for the sand and from $0.09-0.30 \mathrm{~m} 3 \mathrm{~m}-3$ for the clay loam) decreased thermal conductivity. 


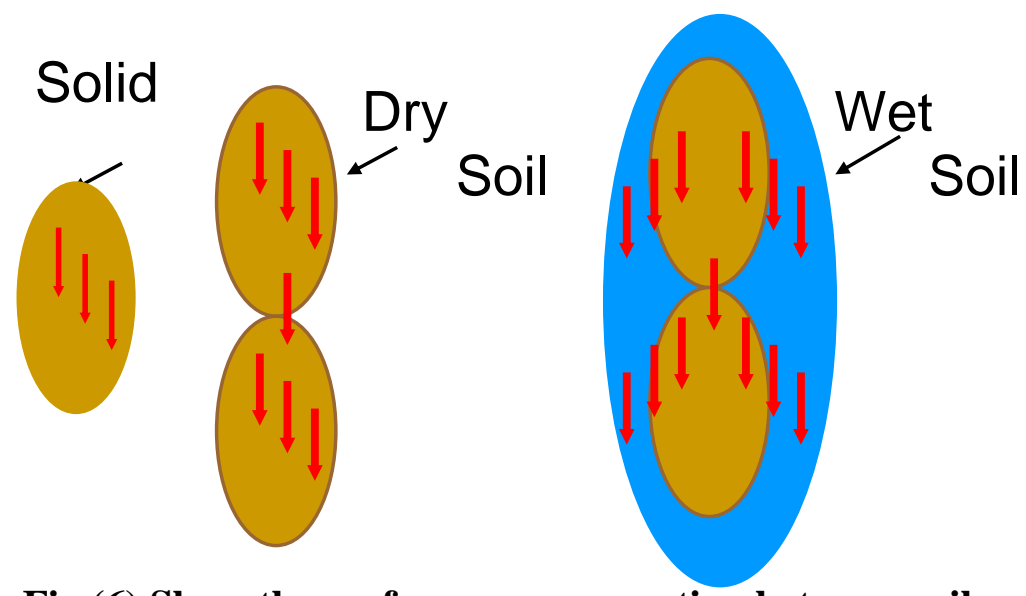

Fig.(6) Show the surface area connection between soil particles in dry case and wet case

\section{Heat transfer rate}

Heat transfer rate of several common used pipes were calculated, and compared with PVC with thermal conductivity $0.19 \mathrm{~W} /(\mathrm{m} \cdot)$. The obtained results are shown in Table (5) .

thermal conductivity of metal pipe with high density is greater than that of PVC about 5.5 times, and heat transfer rate of galvanized steel pipe with high density is 4to 4.5 than that of PVC. So, according to the analysis above, it is suggested to adopt metal pipe with high density as buried pipe of underground heat exchanger. And the increase of soil thermal conductivity, heat transfer quantity obviously increases. And when thermal conductivity increases from $0.19 \mathrm{~W} /(\mathrm{m} \cdot \mathrm{K})$ for PVC to 16.2 $\mathrm{W} /(\mathrm{m} \cdot \mathrm{K})$ for metal, heat transfer quantity rise from $839 \mathrm{~W} / \mathrm{m}$ to 5137.7 $\mathrm{W} / \mathrm{m}$, which is estimated to increase about $550 \%$. It indicates that soil thermal conductivity have great influence on heat transfer.

Table 5. Heat exchange rate of different types of pipes in two types of soil in fifteen minute

\begin{tabular}{|c|c|c|c|c|c|c|}
\hline \multirow{2}{*}{$\begin{array}{c}\text { air } \\
\text { velocity }\end{array}$} & \multicolumn{5}{|c|}{ Heat transfer quantity of one-meter length pipe (W/m) } \\
\cline { 2 - 7 } & \multicolumn{3}{|c|}{ Sandy soil } & \multicolumn{3}{|c|}{ clay loam soil } \\
\cline { 2 - 7 } & PVC & steel & galvanizd steel & PVC & Steel & galvanized steel \\
\hline 0.7 & 839.7 & 5137.7 & 4382.4 & 944.7 & 5548.4 & 4695.9 \\
\hline 1 & 980.5 & 5799.6 & 5062.8 & 1153.5 & 5976.7 & 5179.6 \\
\hline 1.5 & 761.3 & 2510.8 & 2433.8 & 908.4 & 3300.4 & 2909.3 \\
\hline
\end{tabular}


The results show also the lower air velocity $0.7 \mathrm{~m} / \mathrm{s}$ enhancing the heat exchange rate between the soil and air and the difference between the inlet air temperature and outlet air temperature is the highest and the lowest at using $1.5 \mathrm{~m} / \mathrm{s}$ but the high heat transfer rate achieved with air velocity $1 \mathrm{~m} / \mathrm{s}$ as shown as Figure(7).

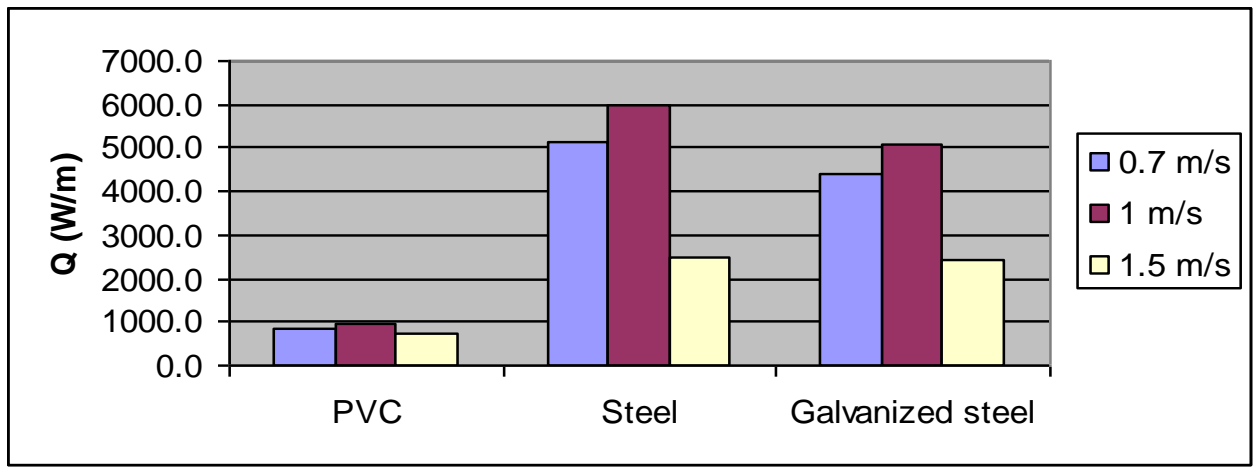

Fig.(7) Heat transfer rate for different pipe materials with different velocities in sandy soil in fifteen minutes.

The interaction between the sandy clay loam and pipe is better than sandy soil and pipes as shown as Figure $\left({ }^{9}\right)$.

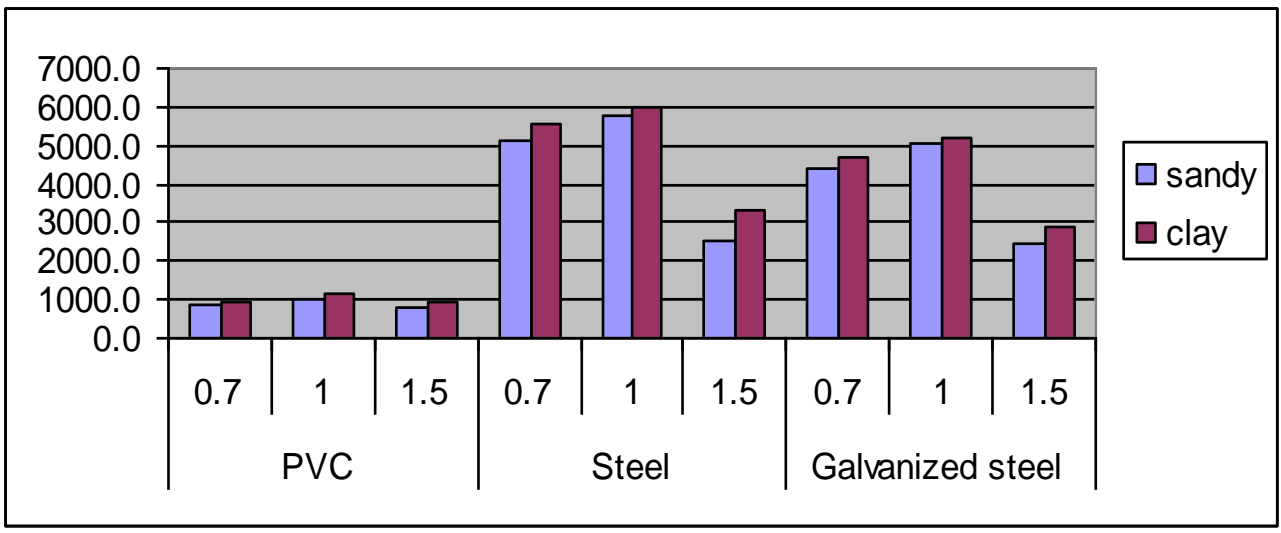

Fig.(8) Heat transfer rate for different pipe materials with different velocities in sandy soil and sandy clay loam soil in fifteen minutes

With increasing in the soil moisture the values of heat exchange rate between the air in the all types of pipes and the soil increase specially in the sandy clay loam where the rate heat exchange increased by 1.5 more 
than the sandy soil figure (10) due to increasing of surface area between pipes material and soil and the high thermal conductivity for water.

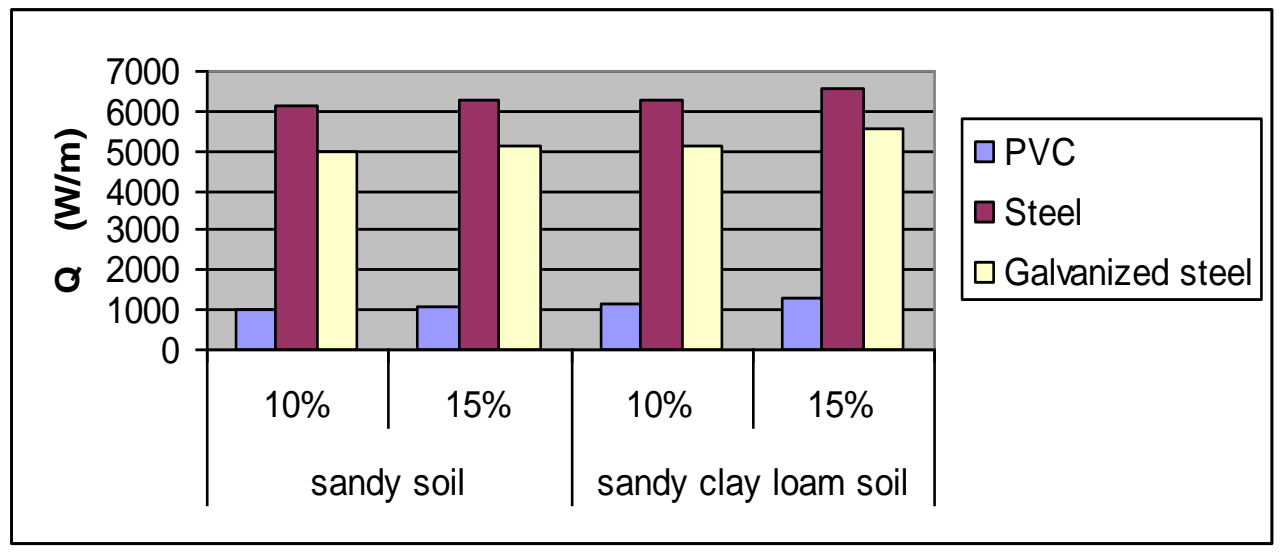

Fig.(9).The heat transfer rate with moisture content in soil $10 \%$ and

\section{$15 \%$ With0.7 m/s air velocity.}

\section{CONCLUSION}

In this paper thermal property of soil are discussed. And the impact of soil thermal conductivity and pipe thermal conductivity on soil temperature field around buried pipe.

The following conclusions can be gained:

1. Soil temperature around the buried pipe increase with the increase of soil thermal conductivity in hot climate.

2. With the increase of soil thermal conductivity, heat exchange rate obviously increases between air in pipes and soil. Soil temperature distribution along the heater is drawing isothermal lines and thermal conductivity in sandy soil is higher than sandy clay loam soil but the area of connection between the pipe and the sandy clay soil is bigger than sandy soil with pipe because the sandy soil has pockets of air.

3. With the increase of pipe thermal conductivity, heat exchange rate and the mean temperature of the buried pipe outside surface all increase. It is suggested to adopt metal pipe with high density as buried pipe because its heat exchange rate is higher 5.5 times to PVC and 1.25 to galvanized steel but there are more specification 
to select the type of pipe like cost, strength, corrosion resistance, and durability.

4. Sandy clay loam soil is preferable to sandy soil. It is suggested to surrounding the pipes with compacted clay to ensure better thermal contact between the pipes and the earth.

5. Wet soil is preferable to dry soil because of better thermal conductivity; peat and dry sand should be avoided.

6. Lower flow rates are beneficial to achieve higher or lower temperatures, because they correspond to lower fan power. However, a compromise has to be made between pipe diameter, desired thermal performance, and flow rate.

\section{REFERENCES}

Bose J E, Parker J D. 1983, Ground -coupled heat pump research [J]. ASHRAE Trans, 89(2):375-390.

Calvin W. Rose. 2004. An Introduction to the Environmental Physics of Soil, Water and Watersheds . 2nd ed. Gordon and Breach Sc. Publishers. (ISBN-13: 9780521536790)

Dunren Guo. 1965. Physics and mathematics method [M]. Beijing: People Education Press, 40-50.(In Chinese)ESL-IC-06-11304

Guozhong Wu, Jiulong Zhang, Yingjie Wang. 2003, Heat transfer calculation of pipeline buried underground [M]. Harbin: Harbin Institute Technology University Press, 7684.(In Chinese)

Holaman, j, p.1986 . Heat transfer. 6nd ed. Gordon and Breach Sc. Publishers. (ISBN-13: 9780521536790)

Hongming Fan, Shouxia Shi, Zhongyi He. 1999. The temperature field analysis of the pipeline buried underground directly $[\mathrm{J}]$. Transaction of Harbin Architecture University, 32(5):6065.(In Chinese)

Michael, J and Howard, N 2007. Fundamentals of engineering termodynamics . Int. J. Food Eng. 3, 1-18. 
Randall J. Schaetzl, Sharon Anderson Color. 2005 . Soils .5th ed.. p. 448. (ISBN-13: 9780521812016$)$

Sabau S S, Tao Y X, Liu G, Vidhuvalavan G. 1997. Effective thermal conductivity for anisotropic granular porpous media using fractal concepts. ASME Proceedings of 32nd National Heat Transfer Conference [C]. New York: ASME Publication.

$$
\begin{aligned}
& \text { الملخص العربي } \\
& \text { دراسة بعض الخواص الطبيعية والحرارية للتربة المبية } \\
& \text { وانابيب المبادلات الحرارية الارضية والية المراية }
\end{aligned}
$$

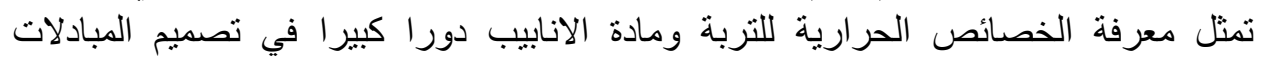
الحرارية الأرضية ولضمان استخدامها بكفاءة عالية. من هذه الخصائص الكثافة الحقيقية والظاهرية ولثانية ومعامل التوائة التوصيل الحراري للتربة للأنابيب

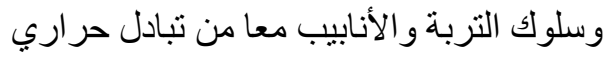

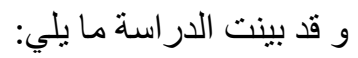
يزداد معدل التبادل الحراري مع التربة بزيادة معامل التوصيل الحراري للانابيب ولنابل وللك كان

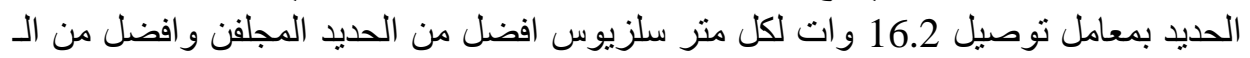
PVC في التبادل الحراري في كلا النو عين من التربة.

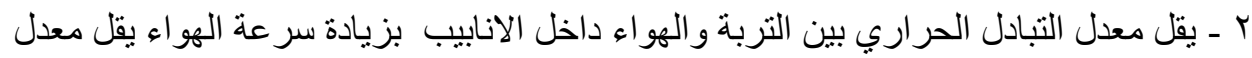

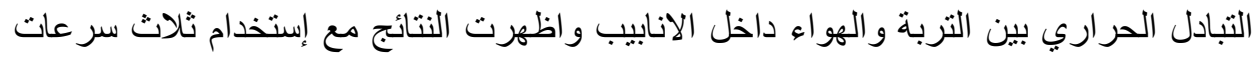

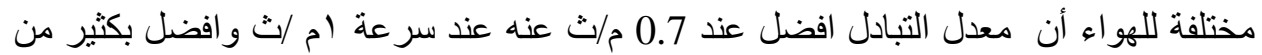

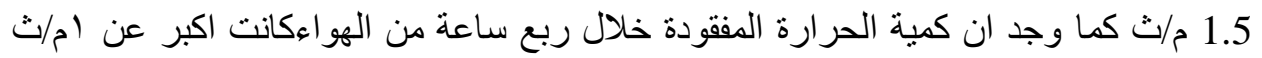

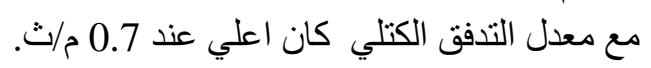

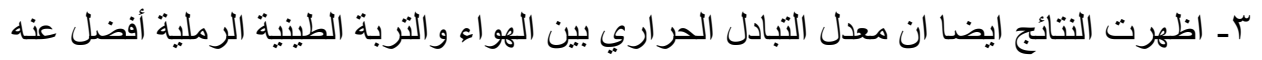

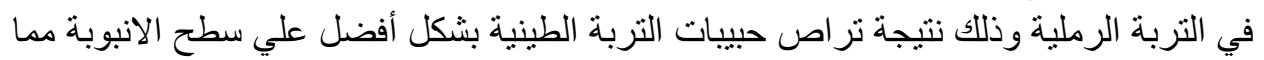
يزيد من مساحة سطح الأتصال بين التربة ولتر الأنابيب.

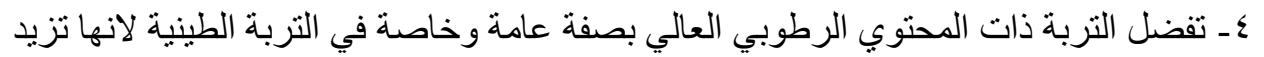

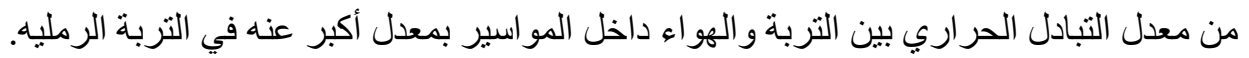

ا استاذ، قسم الهندسة الزراعية ـ كلية الزراعة - جامعة القاهرة

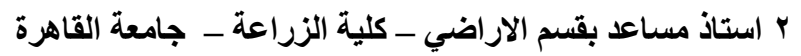

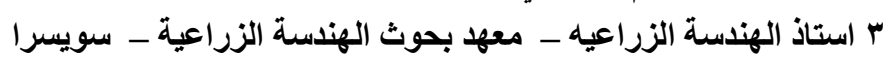
ع معيد بقسم الهندسة الزراعية ـ كلية الزراعة ـ جامعة القاهرة 